\title{
INTEROPERABILITY CADASTRAL DATA IN THE SYSTEM APPROACH
}

\author{
Monika Mika ${ }^{1}$ \\ 1 Faculty of Environmental Engineering and Land Surveying, Department of Land Surveying, University of \\ Agriculture in Krakow, Balicka 253a, 30-198 Kraków, Poland, e-mail: momika@ar.krakow.pl
}

Received: 2016.12.21

Accepted: 2017.01.24 Published: 2017.03.01

\begin{abstract}
Elements of each system and their interrelationships can be represented using models simulating reality. Analysis of the problem with the use of modeling methods facilitates the identification of the problem, its diagnosis and assessment of data quality. In this study, the method of semantic modeling, based on the principles of system analysis was used. The thematic scope of the publication covers the use of these methods in order to develop a model of cadastral data in Poland. Real estate cadastre is one of the most important information systems in the world, based on the spatial data of geodetic and legal nature. It is therefore important to define appropriately its purpose, scope of data and the links between objects, subjects and their assigned rights. The methods of system analysis are widely used for this purpose around the world. By using of these methods the schematic diagram of the multi-purpose cadastre in Poland was developed, along with the model of sources and types of cadastral information. Particular attention was paid to modeling of the scope and content of spatial data. The basic assumption of the functionality of the cadastral system is the interoperability of data, from selected databases collecting information about cadastral objects with the use of thematic groups if the INSPIRE Directive. Spatial conditions of data interoperability of modeled multipurpose cadastre based on current law conditions in Poland were presented in this paper.
\end{abstract}

Keywords: cadastre, spatial data, data modeling, INSPIRE, SDI

\section{INTRODUCTION}

The subject matter of this publication concerns the system analysis of one of the most important information systems, based on spatial data of geodetic and legal nature, which forms the backbone of the real estate management, which is the real estate cadastre. The important stage of the analysis was modeling of the scope and content of the cadastral data in the system approach. The basic assumption of the cadastral system functionality is the interoperability of data derived from different databases, containing information about cadastral objects, in accordance with applicable law.

In Poland, Land and Buildings Registry serves as the cadastre. It is a public register, containing mainly information about the factual condition of cadastral objects (parcel, building, premises). According to the current Land and Buildings Reg- istry a uniform for the whole country, regularly updated set of information about land, buildings and premises, their owners and other natural or legal persons, possessing the land, buildings and premises. The data contained in Land and Buildings Registry are the basis of economic planning, spatial planning, determining the size of taxes and services, placing the property in land and mortgage registers, public statistics and real estate management. Information on land, buildings and premises is included in the registry documentation, which consists of maps, records and documents justifying the entries to these registers. These documents coexist in digital and analog forms. From the point of view of modeling information on terrain, for the needs of real estates cadastre modification, in the aspect of multi-purpose - these data are insufficient, because they do not contain reliable (credible) information on the legal status of these objects [Kwartnik Pruc 
2014, Mika, Siejka et al. 2016]. The legal status of the property is included in Land and Mortgage Register System. Between the data recorded in these systems there are many differences resulting from many causes, described inter alia in [Przewięźlikowska and Buśko 2014] and requiring a rapid correction. In recent years, the aim is to form in Poland ZSIN - Integrated Information System for Real Estate, connecting a number of databases on one platform. This system would meet European standards for achievement, storage, update, processing and data sharing and could act as a cadastre in Poland. At the moment, however, it is not yet fully ready [Dawidowicz et al. 2014]. So it seems advisable to develop an alternative solution, which attempt was made in this publication.

The analysis of this problem was undertaken using modeling methods. This method facilitates the identification of problems in the way of mutual relations between system components. In this study the methods of semantic modeling were used, based on the graphic notation system analysis [Robertson and Robertson 1999]. In modeling of cadastral data it is important to know the standards and the standardization of data. This has been presented inter alia in [International Organization for Standardization (ISO), Geographic InformationLand Administration Domain Model (LADM), ISO 19152, International Organization for Standardization (ISO): Geneva, Switzerland, 2012]. Modeling of cadastral data in the world aims to create a multi-dimensional cadastral system.

The importance and topicality of the subject matter emphasized in world literature [Aien et al. 2015, Ji-yi Zhang et al. 2016, Aien et al. 2013, Ledoux and Meijers 2011]. According to Aien et al. [2015] "Building Information Models (e.g., IFC) and virtual 3D city models (e.g., CityGML) are revolutionising the way we manage information about our cities. However, the main focus of these models is on the physical and functional characteristics of urban properties and facilities, which neglects the legal and ownership aspects. In contrast, cadastral data models, such as the Land Administration Domain Model (LADM), have been developed for legal information management purposes and model legal objects such as ownership boundaries without providing correspondence to the object's physical attributes".

It is therefore important at the stage of the modeling of cadastral data have regard to both legal and physical attributes of objects. The basis for success is, however, topological correctness of the objects in 2D space [Mika and Len 2016].

While Ji-yi Zhang et al. [2016] states: "The unification of geometric and topological representations is one of the objectives in cadastral data modeling. The key to integrating geometry and topology is the integrated representation of the geometric structure and the dimensional structure of geometric elements of different dimensions".

The development of cities and multidimensional architectural objects caused the need to analyze cadastral data in multiple dimensions, both in the physical and legal space. Aien et al. [2013] write about it: "Digital 3D cadastres are often envisaged as the visualisation of 3D property rights (legal objects) and to some extent, their physical counterparts (physical objects) such as buildings and utility networks on, above and under the surface. [...] A 3D cadastral data model needs to reflect the complexity and interrelations of 3D legal objects and their physical counterparts".

In Poland, Karabin [2012], Bydłosz [2012], Siejka et al. [2014] Mika et al. [2016] deal with the 3D cadastre among others. Earlier studies [Mika 2016, Maślanka 2016], have demonstrated the necessity of modernization of cadastral data in Poland, both in the legal and factual terms.

The opportunities offered by modern tools such as CAD, GIS and DBMS, allow for rapid implementation of the information contained in many databases, but they do not automatically verify defects and inaccuracies which occur in them.

For the needs of development of real estate cadastre in Poland, databases presented in Figure 2 can be used, in the context of obtaining full cadastral information about the real estate. These databases are the data registers of spatial objects (real estate) in 2D, and also record certain features of the 3D. Furthermore, they contain detailed information about the date and scope of changes entered in the records. It can be stated that this type of data concerns changes of space management in time and is part of 4D cadastral system.

The results of the work Siejka et al. [2014], show, that there are possibilities for the gradual creation of 3D cadastre + time in Poland. In the first stage of the cadastre operation it should be based on a simplified model of space time. The next stage of cadastre modeling should be based on the georelational model of spatial data. In this model, cadastral objects will have 3D geometry and topology and temporal attributes. 
As previously mentioned, in Poland the legal and factual state of 2D cadastre has to be organised first in databases used for the construction of Real Estate Cadastre, and only then cadastral data can be extended by another dimension.

\section{METHODS AND RESULTS}

\section{Modeling of objectives and tasks the Real Estate Cadastre}

Real estate cadastre (according to FIG) is understood as a methodically arranged public list of data concerning real estate, based on measurements of their borders. The leading object in Real Estate Cadastre is a property (not a parcel), and the subject and his rights should be linked to the given property. The term of a land property - means land with components, with the exception of buildings and premises, if they constitute a separate object of ownership. On the other hand a parcel of land - constitutes undivided, continuous portion of the earth's surface forming a part or all of a real estate.

Thus defined real estate cadastre should be interoperable database system, whose primary goal is registration of the ownership range to the land property and/or objects associated with them (building, equipment, premises - as a separate part of the building) being the ownership separate from land. The scope of the subjective and objective data recorded in it should give a guarantee of their credibility. In addition to fiscal functions it should serve as a protection for property ownership rights, maintaining the multitude of processes in it: acquiring, processing, storing, updating and sharing of data. The basis for its creation in Poland should be the full integration of data of the Land and Buildings Registry and the Land and Mortgage Registers, after prior verification of the information collected in these systems. This problem should be solved at the local level (district or region). As a public register, containing fair and reasonable legal information about objects and their associated rights, Real Estate Cadastre should be the basis for all planning, economic and technical processes, closely associated with the surveying tasks for the needs of real estate management. After having completed the real estate value data, Real Estate Cadastre function will be to improve the real estate market in the range of the transactions taking place in it. Dawidowicz [2014] writes about it, among others. The graphic part of cadastre should be fully linked with the descriptive part and kept in a form of a digital map. The determining spatial attribute of the land real estate should be the coordinates of the border of land (and building), obtained on the basis of direct measurements. In exceptional and legally justified cases, photogrammetric methods of acquiring or processing data should be considered (based on high-resolution aerial photos). Figure 1 shows a schematic diagram of the multi-purpose cadastre, possible to implement in Poland (but required further gradual changes of regulations and law).

\section{Sources and types of cadastral information}

According to Hopfer [2005] data are the representation of facts, concepts and commands in the formulated manner, easy to transfer, interpretation, or processing by a human or computer. This data can be in the narrative or spatial form. On the other hand the information can be defined as the knowledge and applications resulting from data collection, constituting the sum or an analysis of the data processed into a form suitable for use by the user. Real Estate Cadastre as the system collects vast amounts of data, from which the user can generate the most important from a subjective point of view, information about the object. This information generally can be called cadastral information, because it concerns the objects registered in it. Figure 2 shows a model of sources and types of cadastral information in Poland.

In the information society of the twenty-first century information is collected on the web platforms, among others, as the active databases. The data collected in this form are data of public nature, including restriction of access to personal data. Access to this group of data should depend on the type of user and purpose or legal interest in obtaining these data.

\section{Spatial conditions of data interoperability of multi-purpose cadastre}

The basic assumption of the presented in Figure 3 is the interoperability of data collected by different systems. The plurality of databases used for its construction is necessary to build up in it full and reliable cadastral information. According to [http://www.piit.org.pl/docu- 


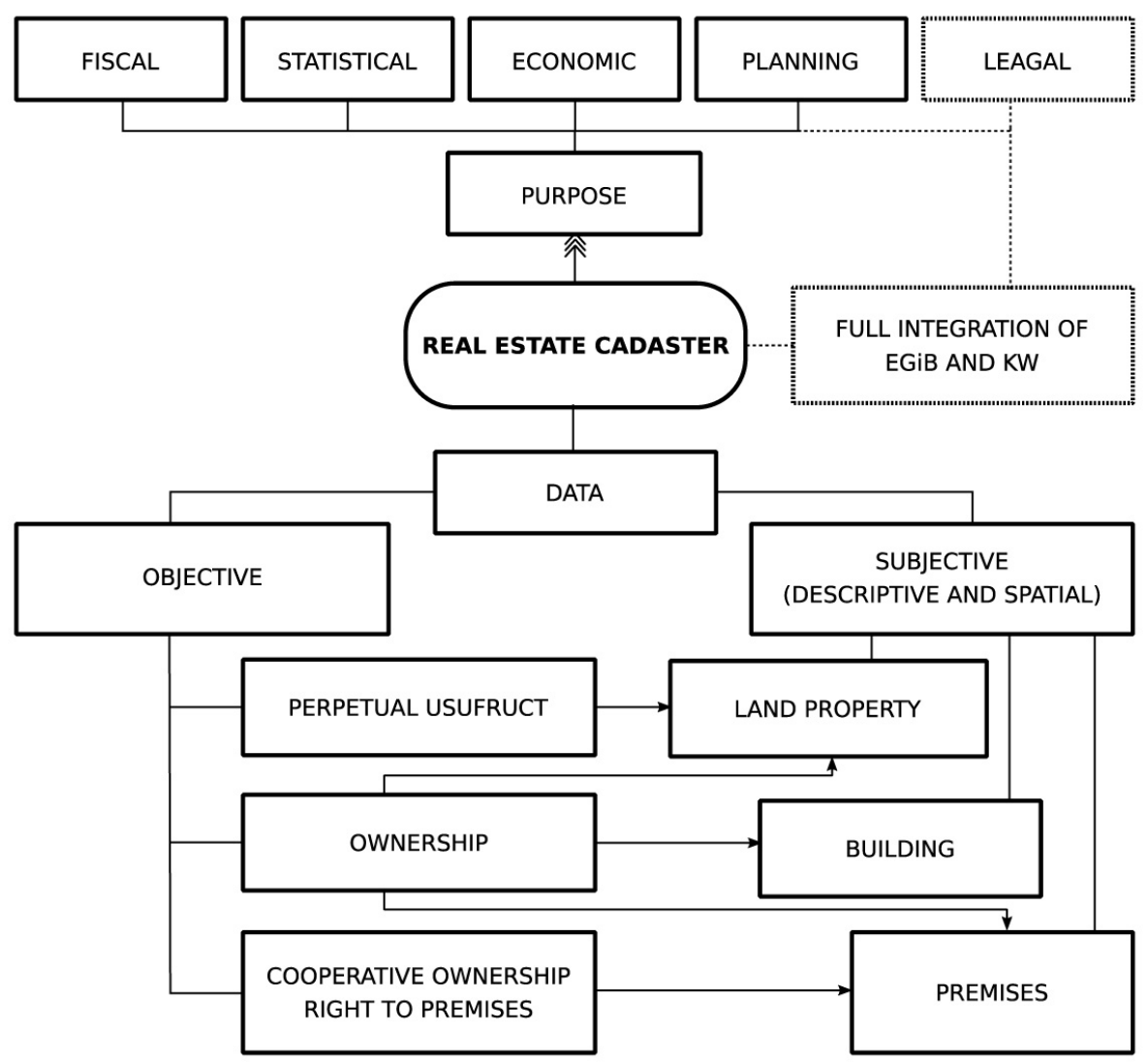

Figure 1. Scheme of objectives and tasks of the multi-purpose cadastre in Poland

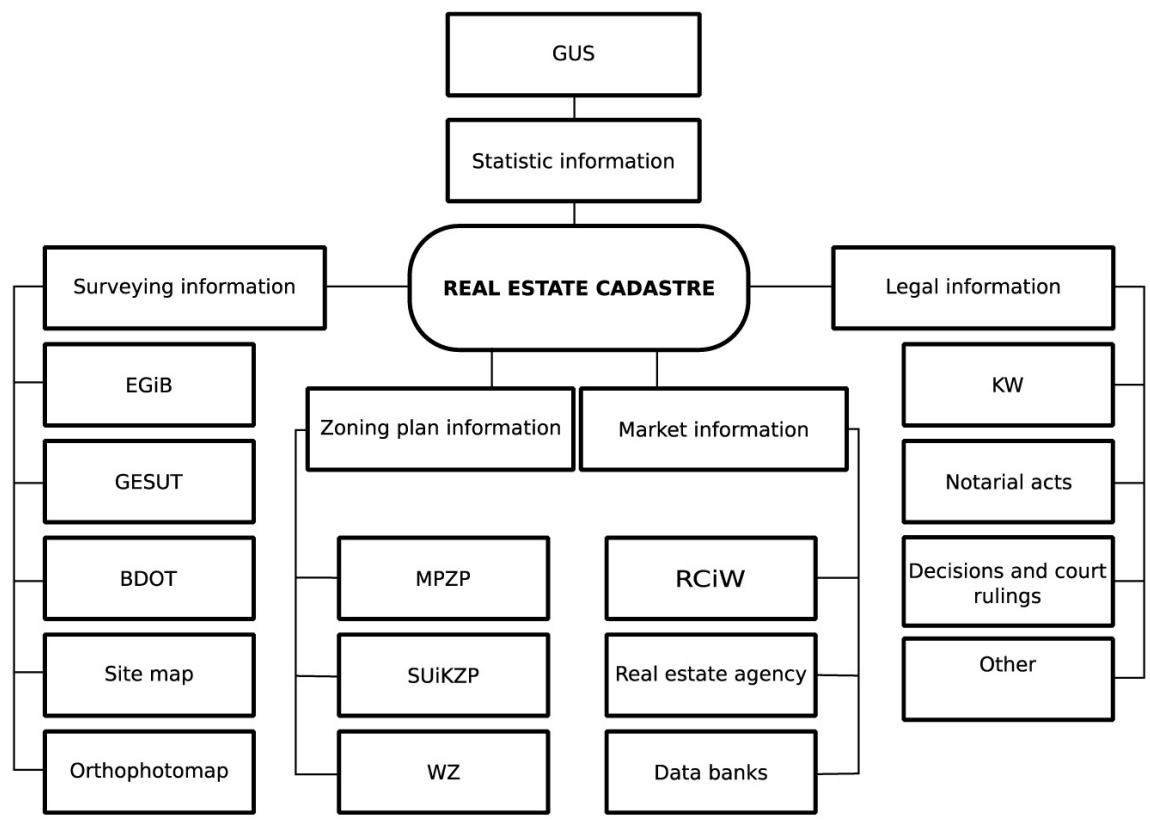

Figure 2. Scheme of sources and types of cadastral information of the modeling Real Estate Cadastre

Where: EGiB - Land and Buildings Registry, GESUT - Geodesic Registry of Infrastructure Network, BDOT database of topographical objects, MPZP local spatial development plans -, SUiKZP - studies of conditions and directions of spatial management of the commune, WZ -, decisions on land development conditions and building permits, RCiW - prices and values register, KW - Land and Mortgage Registers, GUS - Central Statistical Office 
ments/10181/18579/8311.pdf access 27.10.2016] interoperability means connecting people, data and diversified systems. Interoperability can be divided into two general categories: technical interoperability and interoperability at the level of users. This distinction is important from the point of view of cadastral data modeling. It should be noted that in the case of the Real Estate Cadastre construction, technologies in recent years have been repeatedly modified, but the legal changes in Poland does not keep pace with this. Technical interoperability is the ability to exchange information between heterogeneous IT networks, applications and their components and thereby combining the products and computer services from numerous databases. In the case of the Real Estate Cadastre, the problem is the diversity in the management of the cadastral data, collected in separate databases. In addition, these data have different territorial range. Eg. Land and Buildings
Registry at local level is run by District Governor's Office and area coinciding with it. While Land and Mortage Registers is run by the District Courts Real Estate Register Departments, the range of which in the terrain does not coincide with the county area. The problem therefore is the suitable integration of data from systems proposed in Figure 2, and an effective security policy of these data. The semantic interoperability means the ability of two or more systems to exchange information and precise and automatic determination of the importance of this information - both by the sender and the recipient. This can be achieved by using predetermined language of the knowledge presentation (UML, GML). The Real Estate Cadastre consisting of multiple databases must have provided organizational interoperability to exchange information and achieving designated tasks. The organizational interoperability of Real Estate Cadastre should be in line

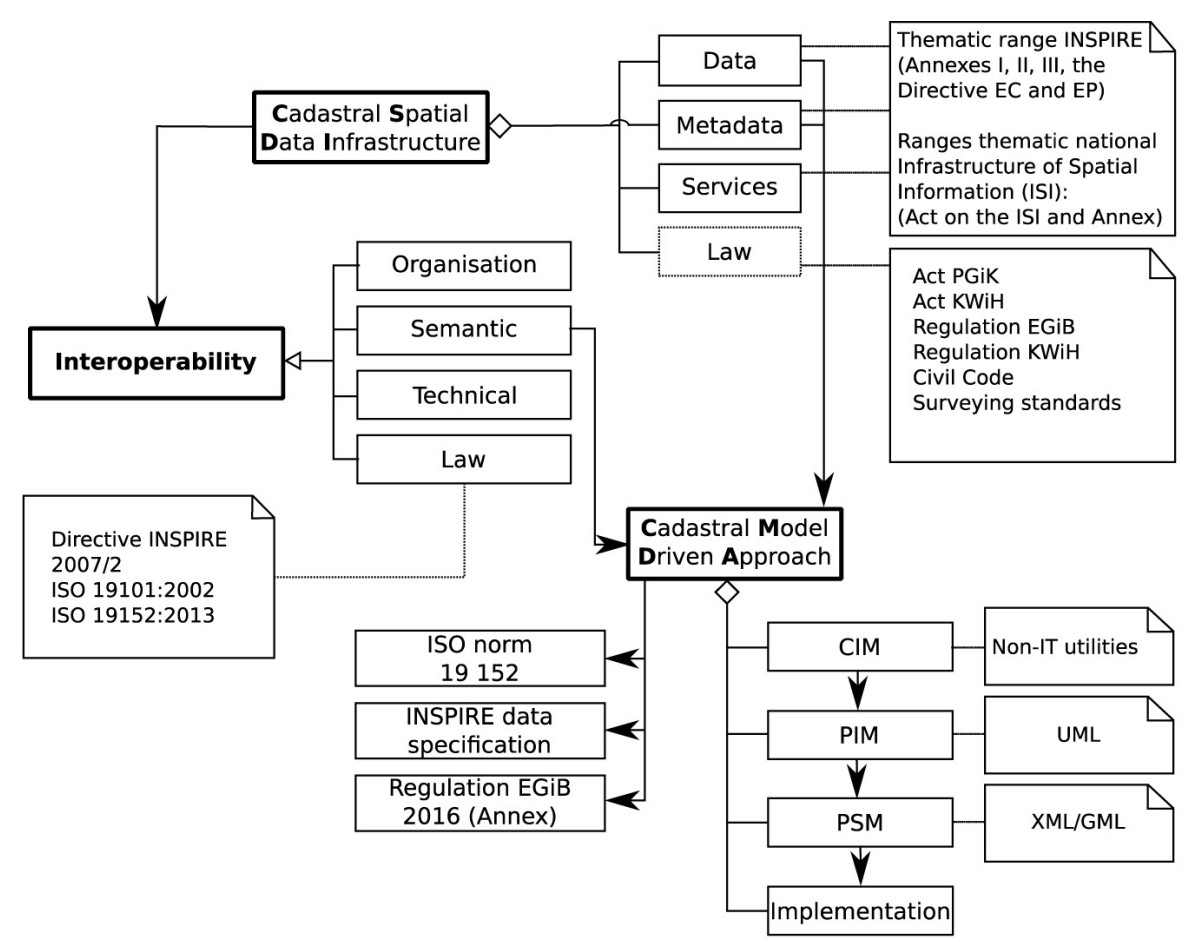

Figure 3. Spatial conditions of data interoperability of multi-purpose cadastre

[based on Pachelski and Zwirowicz-Rutkowska 2016]

Where: Act PGiK - The Act of 17 May 1989 Surveying and Cartographic Law, Act KWiH - The Act of 6 July 1982 on Land and Mortgage Registers and Mortgages, Regulation EGiB - Regulation of the Minister of Administration and Digitization of 29 November 2016 amending the regulation on land and buildings registry, Regulation KWiH - Regulation of the Minister of Justice of 15 February 2016 on the establishment and operation of land registers in the ICT system, Civil Code- The Act of 23 April 1964 The Civil Code, Act on the ISI - The Act of 4 March 2010 on Infrastructure of Spatial Information, INSPIRE - Directive 2004/17/EC of the European Parliament and of the Council of 14 March 2007 setting up an infrastructure for spatial information in European Union, Surveying standards- Regulation of the Minister of Internal Affairs and Administration of 9 November 2011 on technical standards of performing land and height survey works and the processing and transfer of results of these measurements to the National Geodetic and Cartographic Resources. 
with the global trends of systems designing, based on the architecture oriented on services providing (SOA Service Oriented Architecture). In the case of Real Estate Cadastre the special attention should be paid to the improvement of the processes occurring in it, not on changing technologies of their automation. All these considerations, contained in this publication, are the preparing stage to the creation of conceptual model of multipurpose cadastral system. Conceptual model is a description of the structure of the information system, ensuring interoperability of data and possible to implement in different IT environment. Figure 3 presents, saved as a UML class diagram, scheme of concepts, technical regulations and data sources; which interpreted as a structure of a process can lead to the creation of multi-purpose cadastral system. The universality of the presented solution should be understood as a system (structural) combination of different aspects of cadastral infrastructure, namely: data, metadata, services and legal regulations - as a matter of IG methodology, semantic interoperability - as its purpose, and MDA methodology, including CIM, PIM, PSM and implementation. The presented approach allows to sustain the validity the system even in case of the modification the scope of data or changes of norms or regulations.

\section{CONCLUSIONS}

The method of system analysis was used for data modeling of the multi-purpose cadastre in this paper. Important element of research was to introduce the spatial conditions of data interoperability of the modeled multi-purpose cadastre. Cadastre is one of the most important information systems, based on the geodetic and legal data. This system forms the backbone of the real estate management. According to [Balawejder et al. 2015] real estate management is seen as a complex dynamic system, in which a special role is played by the real estate market conditions. Real Estate Cadastre is a development mechanism of the real estate management and is an information system powered by local land information systems (LIS) and other databases concerning real estate. The basis of the cadastral system is full integration of data of the Land and Buildings Registry and the Land and Mortgage Registers.

The development of the process of building a complex information system shown in Figure 3, compatible with the idea of multipurpose cadastre (shown in Fig. 1), leads to the creation of a universal model of cadastre, perhaps including even cadastral tax, as the third type of records, in addition to Land and Buildings Registry and the Land and Mortgage Register. The practical form of implementation of the model seems to be the methodology of integration and harmonization of data, used in the cited regulations. The essence of the study is the creation of compatible models of the same conceptual category in the registers highlighted in Figure 2. Eg. models of the plot in Land and Buildings Registry and the Land and Mortgage Register differ as to the lists of attributes, operations and relationships. Created general class (abstract) ,parcel"= "land real estate”, would contain only those attributes, operations, relationships that are common to the class "plot" in all registers, included in the multi-purpose cadastre. These attributes (operations, associations) would be inherited by the ,parcel"= "land real estate"specialized subclasses in these registers, which, moreover, could contain their own attributes (operations, associations).

The implementation of a cadastral system (Figure 2) required further gradual changes of regulations and law:

- STEP 1. The new law on real estate cadastre (including the development of organizational structures).

- STEP 2. Establishing the base object as "land real estate",

- STEP 3. Verification of incompatibilities between the Land and Buildings Registry and the Land and Mortgage Registers.

- STEP 4. Introduction of data protection of cadastral data for various user groups.

- STEP 5. The gradual transition to 3D cadastre, using all available databases, meeting the precision criteria.

\section{REFERENCES}

1. Aien A., Rajabifard A., Kalantari M., Shojaei D. 2015. Integrating legal and physical dimensions of urban environments. ISPRS Int. J. Geo-Inf., 4, 1442-1479.

2. Aien A., Kalantari M., Rajabifard A., Williamson I., Wallace J. 2013. Towards integration of 3D legal and physical objects in cadastral data models. Land Use Policy 2013, 35, 140-154.

3. Balawejder M., Busko M., Cellmer R., JuchniewiczPiotrowska K., Leń P., Mika M., Szczepankowska 
K., Wójciak E., Wójcik-Leń J., Źróbek S. 2015. Aktualne problemy Gospodarki nieruchomościami w Polsce na tle przemian organizacyjno-prawnych. Monografia Wyższej Szkoły InżynieryjnoEkonomicznej w Rzeszowie. Rzeszów, pp. 144.

4. Bydłosz J. 2012. The multi-dimensional cadastre and its implementation conditions in Poland. Annals of Geomatics. 2012. Polskie Towarzystwo Informacji Przestrzennej, 10, 3, 47-54.

5. Dawidowicz A., Radzewicz A., Renigier-Biłozor M. 2014.Algorithm for purposes of determining real estate markets efficiency with help of land administration system. Survey Review, 46, 336, 189-204. DOI: $10.1179 / 1752270613$ Y.0000000080.

6. Directive $2007 / 2 / E C$ of the European Parliament and of the Council of 14 March 2007 establishing an Infrastructure for Spatial Information in the European Community (INSPIRE). Available online: http://eur-lex.europa.eu/LexUriServ/ LexUriServ. do?uri=OJ:L:2007:108:0001:0014:en:PDF (accessed on 15 April 2016).

7. Hopfer A, Bojar Z., Cymerman R., Michnikowska K., Nurek W., Prystupa M., Szymański M. 2005. Informacje w wycenie nieruchomości. PFSRM Warszawa.

8. Ji-yi Zhang, Peng-cheng Yin, Gang Li, He-he Gu, Hua Zhao and Jian-chun Fu 2016. 3D Cadastral Data Model Based on Conformal Geometry Algebra. ISPRS Int. J. Geo-Inf. 5, 20. DOI: 10.3390/ ijgi5020020.

9. Karabin M. 2012. Registration of untypical 3D objects in Polish cadastre - do we need 3D cadastre? Geodesy and Cartography, 61, 2, 61-71. DOI: 10.2478/v10277-012-0023-8.

10. Kaufmann J., Steudler D. 1998. Cadastre 2014 a vision for a future cadastral system. FIG-Commission 7 Working group (1994-1998) "Vision Cadastre".

11. Kwartnik Pruc A. 2014. Practical Problems of Delimitation of Real Estate under the Provisions of the Water Law. Geomatics and Environmental Engineering, 8, 3, 94-106.

12. Ledoux H., Meijers M. 2011. Topologically consistent 3D city models obtained by extrusion. International Journal of Geographical Information Science, 25, 4, 557-574. DOI: 10.1080/13658811003623277.

13. Maślanka J. 2016. Koncepcja modernizacji ewidencji gruntów i budynków w aspekcie potrzeb harmonizacji i interoperacyjności baz danych ewidencyjnych. Rozprawa doktorska AGH, tekst niepublikowany, pp. 290.

14. Mika M. 2016. Proposals for changes in surveyinglegal procedures for the needs of cadastre in Poland. Reaports on Geodesy and Geoinformatics, vol 102, Issue 1, 67-77. DOI: 10.1515/rgg-2016-0028.

15. Mika M., Leń P. 2016. Analysis of the faulty spatial structure of land in the context of assessing the quality of cadastral data in Poland. 16th International Multidisciplinary Scientific GeoConference SGEM 2016, Albena, Bulgaria, www.sgem. org, SGEM2016 Conference Proceedings, June 28 - July 6, 2016, Book 2, Vol. 2, 91-100. DOI: 10.5593/SGEM2016/B22/S09.013.

16. Mika M., Siejka M., Leń P., Król Ż. 2016. The Concept of Using the Water Cadastre Databases Components for the Construction of Multidimensional Cadastre in Poland, Survey Review, access online. DOI: 10.1080/00396265.2016.1263180.

17. Pachelski W., Zwirowicz-Rutkowska A. 2016. Ocena potrzeb oraz metodyka kształcenia w zakresie modelowania informacji geograficznej dla celów budowy infrastruktury informacji przestrzennej. Materiały konferencyjne z Konferencji Naukowo-Technicznej „Współczesne problemy geodezji i ochrony środowiska", 19-20 maja 2016 Uniwersytet Przyrodniczy w Lublinie.

18. Przewięźlikowska A., Buśko M. 2014. The analysis of the updating time of subject and object data due to the information flow between the systems of the real estate cadastre and the land and mortgage register. 14th International Multidisciplinary Scientific Geoconference (SGEM), Albena, Bulgaria, Jun 17-26, 2014. Geoconference On Informatics, Geoinformatics And Remote Sensing, Vol III Book Series:International Multidisciplinary Scientific GeoConference-SGEM 933-940.

19. Robertson J., Robertson S. 1999. Pełna analiza systemowa. Wydawnictwo Naukowo-Techniczne Warszawa, pp. 573.

20. Siejka M., Ślusarski M., Zygmunt M. 2014. 3D+time Cadastre, possibility of implementation in Poland. Survey Review, 46 (335), 79-89. DOI: 10.1179/1752270613Y.0000000067.

21. Steudler D., Williamson I.P. 2005. Evaluation of National Land Administration System in Switzerland. Case Study Based on a Management Model. Survey Review, 38(298), 317-330. DOI: 10.1179/ sre.2005.38.298.317. 